\title{
$>$ A dialética da música em Dona Flor e seus dois maridos
}

$>$ The dialectic of music in Dona Flor e seus dois maridos

\section{por Paulo Augusto Nedel}

Doutorando em Estudos de Literatura na linha de pesquisa Pós-colonialismo e Identidades do Programa de Pós-graduação em Letras da Universidade Federal do Rio Grande do Sul (UFRGS). E-mail: professor.paulonedel@gmail.com. ORCID: 0000-00026861-7774.

\begin{abstract}
Resumo
Este estudo visa a analisar o papel da música na obra Dona Flor e seus dois maridos, de Jorge Amado. Evidenciada por referências de acompanhamento nos títulos dos capítulos, citações de músicas e cantores reais inseridos como personagens, assim como em vários momentos importantes na obra, a música desenvolve uma relação dialética, representada principalmente por Vadinho e Teodoro. A partir desses dois personagens, dois mundos se opõem: o popular, da malandragem, do amor sensual, e o erudito, da seriedade, do amor compromissado e respeitador. Em meio a esse cenário, tem-se a figura de Flor, sempre obrigada a escolher entre um ou outro, entre seus dois maridos, seus caráteres tão opostos e também seus tipos de música, que tanto os caracterizam.
\end{abstract}

Palavras-chave: Literatura Brasileira. Jorge Amado. Relação Literatura/Música.

\section{Abstract}

This study aims to analyze the role of music in the novel Dona Flor e seus dois maridos, by Jorge Amado. Music develops a dialectic relationship which is strongly epitomized by Vadinho and Teodoro and is shown in various important moments of the novel. For instance, the title of each chapter of the book accompanies lyrics and excerpts of songs and real singers function as actual characters in the story. These two characters cause two different worlds to oppose to one another: one which is characterized by mundaneness, mischief and sensual love, and another which is characterized by erudition, earnestness and respect. In this scenario, Flor is forced to pick one of her two husbands, whose characters and tastes for music are so contradictory.

Keywords: Brazilian Literature. Jorge Amado. Relationship between Literature and Music. 
Estava sambando, numa animação retada, e sem avisar nada a ninguém caiu de lado já todo cheio de morte.

Jorge Amado, Dona Flor e seus dois maridos.

Dona Flor e seus dois maridos, publicadoem 1966, éum dos livros mais populares de Jorge Amado. Com mais de 50 edições e publicada em mais de 20 países, a história alcançou maior fama ao ser lançada no cinema em 1976. Dirigido por Bruno Barreto, foi por 34 anos o filme brasileiro com maior público: mais de 10 milhões de telespectadores. Uma adaptação televisiva em 1998 aumentou ainda mais sua popularidade.

No entanto, o que possivelmente escapou a muitos leitores, e com certeza aos telespectadores, é a ligação fortíssima que a obra mantém com a música. Não se trata de um tipo de música especifico, mas, sim, com a música em geral, e em todos os sentidos. Isso se demonstra mais claramente em três aspectos no romance:

(1) A música está presente em vários momentos da vida dos personagens, tanto dos principais, como Vadinho, Flor e Teodoro, quanto de alguns dos secundários, e até daqueles que são citados apenas uma ou poucas vezes;

(2) A referência à música configura-se uma oportunidade de citação de nomes, personagens e acontecimentos reais que aparecem na história, dando a ela um caráter mais verossímil, ou, na intenção do autor, verdadeiro;

(3) A ligação entre o tipo de música e a personalidade dos personagens cria uma situação dicotômica:

POPULAR versus ERUDITO

MALANDRAGEM versus SERIEDADE

VADINHO versus TEODORO 
Vejamos cada um desses três pontos que, amiúde, se entrecruzam. Sobre o primeiro, o da relação da música com momentos da vida dos personagens, deve-se levar em consideração que a obra começa com a morte de Vadinho, como se vê:

Vadinho o primeiro marido de dona Flor, morreu num domingo de carnaval, pela manhã, quando fantasiado de baiana, sambava num bloco, na maior animação, no Largo Dois de Julho, não longe de sua casa. (...) O bloco conduzia uma pequena e afinada orquestra de violões e flautas; ao cavaquinho, Carlinhos Mascarenhas, magricela celebrado nos castelos, ah! um cavaquinho divino. ${ }^{1}$

Ou seja, quando Vadinho morre, uma orquestra está tocando. E assim será no restante da obra, pois a música acompanha a vida - e a morte de um - dos três personagens principais: Flor, Vadinho e Teodoro.

Após a morte de Vadinho, na casa de Flor, onde se realiza o velório, acontece o mesmo. Não há música na casa, mas:

Lá fora era o carnaval com seus mascarados, seus blocos e ranchos, suas fantasias ricas ou divertidas. A música das multiplicadas orquestras, os zé-pereiras, os zabumba, os blocos, os ranchos, afochês com seus tamborins e atabaques. ${ }^{2}$

Vadinho conheceu Flor em um baile na casa do Major Tiririca, onde ele e Mirandão entraram de penetras. A cena inicia com Mirandão se apresentando a Dona Rozilda, mãe de Flor, e observando o casal dançar:

(...) estendeu as pernas, ajustou cuidadoso o vinco das calças, analisando os pares num tango argentino caprichado, figurações difíceis, passos quase acrobáticos, sorriu aprovativo: nenhum dançarino podia comparar-se a Vadinho, nenhum com sua classe (...). ${ }^{3}$

Essa música irá se repetir em um momento muito significativo para dona Flor, no dia de seu último aniversário antes da morte de Vadinho, depois de sete anos de casamento. Finalmente conseguira que o marido realizasse seu sonho de levá-la para jantar no melhor cassino de Salvador, apesar de todas suas tentativas de afastá-la daquele seu mundo de jogo e farra:

\footnotetext{
${ }^{1}$ Jorge Amado, Dona Flor e seus dois maridos, 1966, p. 21.

${ }^{2}$ Ibidem, p. 30.

${ }^{3}$ Ibidem, p. 87.
} 
No salão do Pálace iam os dois a dançar, num tango de doçura e de volúpia, tão de jovens inocentes namorados e tão de lúbricos amantes. Era como se houvessem retornado ao fascínio da casa do Major, ao impacto do primeiro encontro, do primeiro olhar, do riso inicial, do enleio; sendo também os maduros amantes de sete anos depois, um tempo longo de padecer e amar. Casta donzela, dona Flor, mocinha cândida; desabrochada mulher e ardente fêmea, dona Flor, nas mãos de Vadinho, seu marido. Tango igual a esse jamais fôra dançado, assim transparente de ternura, assim obscuro de sensualidade. Até da sala de jogo veio gente apreciar. ${ }^{4}$

Ainda quando vivo, Vadinho fez serenatas para dona Flor, pedindo-lhe desculpas pelas suas faltas: uma quando Flor descobriu que ele era, na verdade, um malandro jogador e outra, feita em grande estilo, depois do casamento. Não as únicas, pelo que indica um trecho no qual dona Flor, já viúva, sente saudade do falecido:

(...) Agora sem espera e sem esperança, de nada servia atentar à cadência dos passos, dos passos dos bêbados sobretudo, ao barulho sutil da chave na fechadura, ao som de uma canção perdida, de uma toada na distância. (...) Sim, de uma toada na distância. Porque houvera noites, durante aqueles sete anos de casamento e espera, em que Vadinho veio acordá-la em serenata, com violão e cavaquinho, violino e flauta, trompete e bandolim, a repetir aquela outra inesquecível serenata da Ladeira do Alvo, quando ela acabara de saber da verdadeira condição de seu amor; pobre, sem vintém, funcionário chinfrim, picareta e facadista, cachaceiro, libertino e jogador. $^{5}$

Nessa primeira serenata, inesquecível para Flor, Vadinho estava acompanhado, entre outros amigos, de Dorival Caymmi:

(...) Caymmi abriu o eco, soltou a voz em dueto com Vadinho, cujos gorjeios não valiam lá grande coisa. Grande era sua causa, sua paixão proibida: o desejo de desagravar a namorada, curar suas tristezas, apaziguar seu sono, trazer-lhe o consolo da música, prova de seu amor:

"Noite alta, céu risonho

a quietude é quase um sonho

e o luar cai sobre a mata

qual uma chuva de prata

de raríssimo esplendor...

Só tu dormes, não escutas

${ }^{4}$ Ibidem, p. 208.
${ }^{5}$ Ibidem, p. 147. 
o teu cantor...

A modinha de Cândido das Neves subia a ladeira mais depressa do que eles, apareciam cabeças curiosas, demoravam-se à janela presas ao fascínio da música, à voz de Caymmi. (... $)^{6}$

Anos depois dessa noite da serenata, após o término da festa de aniversário de um ano de casamento com o doutor Teodoro, a história adquire um novo contorno. Enquanto dona Flor se despedia dos últimos convidados, sua amiga Marilda "partiu a cantarolar um tango-canção de serenata, aquele: noite alta, céu risonho, a quietude é quase um sonho..., o de dona Flor, enterrado no carrego do defunto"7. É nessa noite que, minutos depois, ao entrar no quarto, Flor encontra Vadinho, que volta da morte, de tanto ela lhe chamar. A mesma música conectava dois acontecimentos tão distantes no tempo, mas também tão importantes na vida de Flor: o retorno de Vadinho após ser desmascarado, e seu retorno para a segunda vida, quando Flor mais precisava dele, mais sentia sua falta.

O doutor Teodoro é outro personagem que tem uma relação muito especial com a música. Além de boticário, era músico, tocava fagote na Orquestra de Amadores Filhos de Orfeu. Foi de sua autoria, inclusive, uma romanza intitulada Arrulhos de Florípedes em homenagem à sua esposa. Extremamente dedicado a seu hobby, suas únicas diversões eram o fagote e as reuniões em casa de outros músicos para ensaiar.

Não são somente os personagens principais que se ligam dessa maneira à música. Alguns secundários também, em especial Marilda, cujo grande sonho de ser cantora de rádio representa na obra o conflito de gerações e o machismo predominante na sociedade da época devido à implicância de seus pais, e posteriormente de um noivo, com tal decisão.

Essa ligação se dá também com outros personagens que são apenas citados uma ou mais vezes e que não desempenham uma importância capital. Dentre

\footnotetext{
${ }^{6}$ Ibidem, p. 124.

${ }^{7}$ Ibidem, p. 414.
} 
eles, pode-se citar dona Êmina, que "cantava canções árabes acompanhando-se ao piano"8, e também os moleques cantando sambas-de-roda numa visita de dona Flor à mulher que ela achava ser amante de Vadinho e estar grávida dele.

Com relação ao segundo aspecto apontado - dos personagens reais citados na obra -, ocorre que são extremamente referenciados em situações da vida comum de personagens como Vadinho, em especial. Ele, principalmente, conhece e é amigo de músicos que realmente existiram, incluídos na história ao lado de outros, fictícios. Como exemplo, tem-se a primeira serenata organizada por Vadinho, na qual, ao lado de amigos como Mirandão, estava um que alcançaria enorme sucesso nacional:

\begin{abstract}
Vadinho reunira para Flor o melhor de quanto existia. (...) Quanto ao violão, dedilhava-o um moço querido de toda a gente por sua educação e alegria, seu jeito modesto e ao mesmo tempo fidalgo, sua competência no beber, sua finura de trato, e sua música: a qualidade única de seu violão, dele e de mais ninguém, e sua voz de mistério e picardia. Um retado. Aparecera ultimamente a tocar e a cantar no rádio, e já o sucesso o cercava. Repetiase o seu nome, Dorival Caymmi, e os íntimos exaltavam suas composições inéditas; no dia em que fossem divulgadas, o moreno ficaria célebre. De Vadinho era amigo do peito, juntos haviam tomado os primeiros tragos e varado as primeiras madrugadas. Traziam de reserva a Jenner Augusto, pálido cantor de cabaré, e de quebra a Mirandão, já bêbado. ${ }^{9}$
\end{abstract}

Como se vê, não só Caymmi é citado, como ainda é amigo de longa data de Vadinho. Ele irá reaparecer na obra, já famoso, tocando no Rio de Janeiro, onde Vadinho o encontra numa viagem, na qual também conhece Sílvio Caldas. Esse último, numa ida a Salvador, será companheiro inseparável de Vadinho, frequentando sua casa, almoçando lá, para alegria e orgulho de dona Flor, e, assim como Caymmi, integrando outra serenata de Vadinho para a esposa que o esperava em mais uma de muitas noites:

Cresce a voz na rua, vai despertando dona Flor, mas o sonho prossegue num milagre, a canção se aproxima, sonho ou realidade? Já se levanta o povo, acorre a ouvir. Dona Flor enfia um robe às pressas, chega à janela. (...) Lá estão eles: Vadinho, Mirandão, Edgard Cocô, o sublime Carlinhos Mascarenhas, o pálido Jenner Augusto dos cabarés de Aracaju. E entre eles, o violão ao peito, a voz desatada, Sílvio a cantar para dona Flor:

\footnotetext{
${ }^{8}$ Ibidem, p. 61.

${ }^{9}$ Ibidem, p. 124.
} 
"... ao som da melodia apaixonada,

Nas cordas do sonoro violão..."

Houvera a serenata, a rua em alvoroço, houvera o almoço no domingo, falado até nas gazetas; na segunda, Sílvio veio preparar o jantar, trouxe de um tudo, vestiu um avental, foi para a cozinha, e sabia mesmo cozinhar. Nos outros dias não tinha hora de aparecer, entrava e saía, juntos foram todos assistir a uma capoeira. Mas, de tudo quanto aconteceu naquela semana, nada se comparou à festa popular da terça-feira, véspera da partida de Sílvio para Recife. Na noite de lua cheia, do alto do palanque no Campo Grande, ele cantou para a multidão, o povo reunido na praça. ${ }^{10}$

Além de Sílvio Caldas, integrou a serenata (e a primeira também) Jenner Augusto, artista plástico sergipano que veio a morar e falecer em Salvador, amigo de Jorge Amado. O autor utiliza muito o recurso de incluir na história personagens reais; por vezes só uma citação, como quando Marilda participa de um programa de calouros na rádio e tira o segundo lugar, perdendo apenas para "um tal de João Gilberto"11.

Se aqui está se dedicando uma atenção maior a Caymmi e Sílvio Caldas, deve-se isso à temática tratada. No entanto, é importante ressaltar que, na história de Dona Flor e seus dois maridos, aparecem também artistas plásticos como Carybé, Mário Cravo e o também babalorixá Mestre Didi, o fotógrafo e sociólogo Pierre Verger e o editor da obra José de Barro Martins. Também estão presentes personalidades do candomblé como Mãe Senhora, Ialorixá do Ilê Axé Opô Afonjá (mãe de Mestre Didi), Mãe Menininha, Ialorixá do Terreiro do Gantois ou Ilê Iyá Omin Axé Iyá Massê, Olga do Alaketu, Ialorixá do Terreiro Ilê Mariolaje, entre outras das personalidades da Bahia.

O que se tem aqui é uma tentativa do autor de dar o máximo de verossimilhança à sua obra. Jorge Amado demonstra essa preocupação com a representação da realidade desde as primeiras páginas, antes mesmo de a história começar, como fica claro com a leitura de um trecho da dedicatória do livro: primeiro para sua esposa Zélia, e em seguida:

\footnotetext{
${ }^{10}$ Ibidem, p. 190 a 191

${ }^{11}$ Ibidem, p. 264.
} 
Para minha comadre Norma dos Guimarães Sampaio, acidentalmente personagem, cuja presença honra e ilustra essas pálidas letras. Para Beatriz Costa, de quem Vadinho foi sincero admirador. Para Eneida que teve o privilégio de ouvir o Hino Nacional executado pelo doutor Teodoro Madureira. Para Giovanna Bonino que possui um óleo do pintor José de Dome - retrato de dona Flor adolescente, em ocres e amarelos. Quatro amigas aqui juntasno afeto do autor. ${ }^{12}$

Antes do primeiro capítulo, o autor também inclui uma carta de dona Flor explicando-lhe uma receita, colocando em baixo, entre parênteses, "Bilhete recente de dona Flor ao romancista"13. Assim, anterior à narrativa, já se tem informações que levam a crer que dona Flor existe, assim como outros personagens. Ela foi, inclusive, pintada pelo artista plástico sergipano José Antônio dos Santos, conhecido como José de Dome, e mantém correspondência com o autor, enviando-lhe receita, na qual até aconselha "dona Zélia a fazer grande de uma vez, pois de bolo de puba todos gostam e pedem mais. Até eles dois, tão diferentes, só nisso combinando: doidos por bolo de puba ou carimã", e afirma que "Compramos mais uma cota da farmácia"14.

No início do capítulo IV, tem-se o convite e o programa da apresentação da Orquestra Filhos de Orfeu, na qual toca fagote o doutor Teodoro. Os capítulos - cinco no total -, importa observar, iniciam sempre com um longo título, preâmbulo do que será narrado, e, em quatro, possuem uma nota com uma música de acompanhamento. Assim, tem-se:

$>$ Capítulo I: Da morte de Vadinho, primeiro marido de dona Flor, do velório e do enterro de seu corpo". "(ao cavaquinho o sublime Carlinhos Mascarenhas). ${ }^{15}$

> Capítulo II: Do tempo inicial da viuvez, tempo do nojo, do luto fechado, com as memórias de ambições e enganos, de namoro e casamento, da vida matrimonial de Vadinho e dona Flor, com fichas e dados e a dura espera agora sem esperança (e a incômoda presença de dona Rozilda). (com Edgard Cocô ao violino, Caymmi ao violão, e o doutor Walter da Silveira com sua flauta encantada). ${ }^{16}$

> Capítulo III: Do tempo do luto aliviado, da intimidade da viúva em seu recato e em sua vigília de mulher moça e carente; e de como chegou, honrada e mansa, ao seu segundo matrimônio quando o carrego do

\footnotetext{
${ }^{12}$ Ibidem, p. 11.

${ }^{13}$ Ibidem, p. 15.

${ }^{14}$ Ibidem, p. 15.

${ }^{15}$ Ibidem, p. 17.

${ }^{16}$ Ibidem, p. 53.
} 
defunto já lhe pesava sobre os ombros. (com dona Dinorá na bola de cristal). ${ }^{17}$

> Capítulo IV: Da vida de dona Flor, em ordem e em paz, sem sobressaltos nem desgostos, com seu segundo e bom marido, no mundo da farmacologia e da música de amadores, brilhando nos salões, e o coro dos vizinhos a lhe recordar sua felicidade. (com doutor Teodoro Madureira num solo de fagote). ${ }^{18}$

> Capítulo V: Da terrível batalha entre o espírito e a matéria, com acontecimentos singulares e pasmosas circunstâncias, possíveis de ocorrer somente na cidade da Bahia, e acredite na narrativa quem quiser. (com um coro de atabaques e agogôs e com Exu a tirar uma cantiga de sotaque: "Já fechei a porta, já mandei abrir."). ${ }^{19}$

Analisando as indicações musicais dos capítulos, tem-se o doutor Teodoro com o mesmo destaque que Dorival Caymmi, ou até mais, se levarmos em conta que o doutor é a única referência de sua indicação, enquanto Caymmi divide a sua com mais dois acompanhantes.

Referir-se a esses personagens é uma forma de o autor criar uma atmosfera de realismo no livro, como se a história que ele está contando realmente tivesse acontecido. Isso tem uma explicação quando se lembra que, num determinado ponto, a história se torna fantástica, com a volta de Vadinho da morte, a influência do candomblé e de toda a mística baiana. São, em seu intuito, pequenas provas de que a história é verdadeira, não inventada pelo autor. O último parágrafo da obra salienta isso:

E aqui se dá por finda a história de dona Flor e seus dois maridos, descrita em seus detalhes e seus mistérios, clara e obscura como a vida. Tudo isso aconteceu, acredite quem quiser. Passou-se na Bahia, onde essas e outras mágicas sucedem sem a ninguém causar espanto. Se duvidam, perguntem a Cardoso e $S^{a}$, e ele lhes dirá se é ou não é verdade. Podem encontrá-lo no planeta Marte ou em qualquer esquina pobre da cidade..$^{20}$

O livro acaba com uma ironia, pois Cardoso e Silva é um místico, mas o que interessa a este trabalho é a intenção do autor em afirmar que, na Bahia, histórias desse tipo não só são possíveis como acontecem mesmo, qualquer um sabe.

\footnotetext{
${ }^{17}$ Ibidem, p. 219.

${ }^{18}$ Ibidem, p. 323.

${ }^{19}$ Ibidem, p. 419.

${ }^{20}$ Ibidem, p. 535.
} 
Intuito de realismo alcançado, sendo necessário, anos depois, em introdução à nova edicão do livro, Jorge Amado explicar que os personagens eram inventados, e citar os nomes de quem lhe auxiliou verdadeiramente com relação à culinária, farmacologia, música etc.

\begin{abstract}
Um fato se repete, constante e monótono, à publicação e cada novo romance do autor desta história de dona Flor e de seus dois maridos: há sempre um(a) cabotino(a) a meter-se na pele de algum personagem e a proclamar em altos gritos o escândalo, fazendo-o através das colunas dos jornais, com publicidade, brilho e ameaças ao romancista: bofetões, processos ou morte. Para impedir suceda o mesmo desta feita, o autor avisa a todos que nejansonnhum vivente aqui, nesta obra de ficção, se encontra retratado. Identidade de nome e sobrenome, de apelido, de profissão, idade, de detalhes físicos ou morais, de feiúra ou de beleza, de celibato, matrimônio ou amigação, de cor de pele, de mistura de sangues, de virtudes e de vícios, de qualidades e defeitos, de tudo, enfim, sem exceção, terá sido a clássica, pura e simples coincidência, ocorrida à revelia do ficcionista. Quis ele fixar apenas aspectos do viver baiano e, em companhia dos leitores, sorrir à custa de certas ambições e certos hábitos da pequena burguesia definitivamente sem jeito, de quando em vez enternecido com essa ou aquela figura torta porém humana. (...) Eis porque qualquer parecença entre a realidade da vida e a realidade do romance - uma nascendo da outra e a recriando - é consequência de experiência e busca; mas, se por azar alguma semelhança existir entre pessoas vivas e personagens do romance, terá sido casual e inocente, por vezes divertida coincidência. ${ }^{21}$
\end{abstract}

Apesar da posterior explicação, é impossível negar a existência dos personagens reais supracitados e sua participação no romance, por vezes apenas em citações, mas também incluídos em eventos importantes da história. A necessidade da advertência do autor sobre a até "divertida coincidência" apenas reforça a ideia de realismo que a obra alcançou.

A realidade da vida e da ficção se misturando e se recriando, como explicou o autor. No site da Fundação Jorge Amado, na página referente ao livro Dona Flor e seus dois maridos, tem-se comentário referindo à sua inspiração para criar a história:

Conta Jorge Amado que, certa feita, conheceu uma senhora que vivia atormentada. Tinha sido casada com um boêmio, enviuvou, casou-se de novo - desta vez, com um português bem comportado. Ia tudo muito bem, até que o primeiro marido começou a aparecer em seus sonhos, querendo ir para a cama com ela. Daí a sua perturbação. Uns trinta anos mais tarde, caminhando com um amigo pelas ruas de Salvador, Jorge Amado viu um sujeito todo vestido de branco, estirado numa escadaria, num tremendo porre. Lembrou-se, de imediato, de um amigo de juventude, Vadinho -

\footnotetext{
${ }^{21}$ Jorge Amado, Dona Flor e seus dois maridos, 2008, p. 11.
} 
sujeito rico, farrista, jogador, que vivia "perdendo dinheiro e ganhando mulheres". Alguns quarteirões adiante, topou com uma placa, fixada na porta de uma casa, onde se lia: Escola de Culinária Sabor e Arte. Para completar o quadro, Jorge Amado e seu amigo se extasiaram, nessa mesma tarde, com a visão de uma belíssima morena, debruçada na janela de um sobrado. Jorge Amado comentou então que, àquela morena deslumbrante, Vadinho certamente teria dito: "quero saborear-te". De repente, as cenas desse passeio a pé por Salvador se fundiram com as imagens da senhora aflita, assediada em sonhos pelo primeiro marido. Tudo se acoplou de tal forma que, no dia seguinte, Jorge Amado já estava em cima da máquina, escrevendo um novo romance. E assim veio à luz, em 1966, a história de Flor, dona da conceituada Escola de Culinária Sabor e Arte, e de Vadinho e Teodoro, seus dois maridos. ${ }^{22}$

O terceiro aspecto se apresenta na forma de uma dicotomia entre o mundo popular, da malandragem, do samba - representado por Vadinho -, e o mundo erudito, sério e responsável - do qual Teodoro é o paradigma. Realmente, Vadinho e Teodoro são totalmente opostos um ao outro. $O$ primeiro voltava frequentemente bêbado para casa, gastava tudo que tinha e o que não tinha, era mulherengo e traia a esposa, sempreestava na rua, na farra, em cassinos eprostíbulos; osegundo raramente bebia, era econômico, prudente, fiel ao extremo e estava sempre presente, no trabalho ou em casa. As diferenças são mais que visíveis. Em um trecho no qual um banqueiro vai fazer um empréstimo ao doutor, enquanto esse cautelosamente pesa os prós e contras de um negócio dessas proporções, há a comparação:

O banqueiro considerou o boticário, tipo honesto, cheio de escrúpulos, incapaz de lesar quem quer que fosse. Não era homem para correr o risco de operação bancária sem a certeza de absoluta cobertura - doutor Teodoro não jogava nunca. Sorriu Celestino: como a vida era surpreendente! Aquela mansa dona Flor, de tímida presença e de tempero insuperável, tomara em casamento os dois homens mais opostos, um o contrário do outro. Imaginouse oferecendo dinheiro emprestado a Vadinho, como agora o fazia ao droguista. As mãos nervosas do rapaz tomariam da caneta e firmariam quanto papel pusessem em sua frente, desde que tais assinaturas lhe rendessem uns mil-réis para a roleta. ${ }^{23}$

Essas distinções servem para mostrar que Vadinho e Teodoro tinham em comum apenas o amor a dona Flor, porém, mesmo isso, de formas totalmente distintas. Vadinho não dava segurança à esposa, mas conhecia-a, sabia tirar-lhe a

\footnotetext{
${ }^{22}$ Fundação Casa de Jorge Amado. Disponível em: <http://www.jorgeamado.org.br/?page_id=148\&lang=pt\&obra=848\&start=20\#obra> Acesso em: 02 set. 2018.

${ }^{23}$ Jorge Amado, Op. Cit., 1966, p. 441.
} 
timidez e amá-la como ela queria; não tinha hora para o sexo, desejando-a nos momentos mais estranhos, a qualquer hora, no meio das aulas de culinária, quase na frente das alunas. Teodoro, ao contrário, tinha dia marcado: sábados, sempre com bis, e quartas-feiras, com bis facultativo. $\mathrm{E}$ o próprio ato sexual era diferente. Vadinho a descobria totalmente, era ousado, malicioso, debochado, o ato sexual era uma brincadeira, uma vadiação, um gozo, como se vê em sua fala para dona Flor no momento da primeira vez:

Não sei vadiar nem coberto de lençol quanto mais vestido com roupa. Tu tem vergonha de quê, meu bem? A gente não vai se casar, não é para isso mesmo? E mesmo que não fosse, a vadiação é coisa de Deus, foi ele que mandou que se vadiasse. "Vão vadiar por aí, meus filhos, vão fazer neném" que ele disse e foi das coisas mais direitas que ele fez. ${ }^{24}$

Teodoro, pelo contrário, era recatado, respeitador, mais envergonhado que dona Flor: cobre-se todo com a coberta na hora de ir para a cama, não troca de roupa na frente da esposa, tem dia e hora marcada para o ato de amor. Já na noite de núpcias com o segundo marido, Flor nota essas diferenças, mas, compreensiva, conclui: "Cada homem era diferente, não existiam dois iguais, bem lhe afirmaram certas alunas de vasta experiência" (...2 ${ }^{25}$.

Da mesma forma, como no tipo de vida e comportamento, Vadinho e Teodoro tinham outra diferença: o gosto musical. Vadinho era do mundo do samba, dos carnavais, das serenatas, da música do povo, como ele. Teodoro pertencia ao mundo da música erudita, de orquestras, música de intelectuais, pessoas finas e educadas, como ele. E essa distinção fica clara quando feita por dona Rozilda, mãe de Flor, que vivia a elogiar o genro farmacêutico e seus ensaios com a orquestra:

- Aquilo, sim, que é música... (...) Dizia-o para louvar as árias, as romanzas, os concertos de fino repertório, onde Hoendel, Lehar e Strauss coexistiam com Othelo Araújo e com o maestro Agenor Gomes, compositores locais menos conhecidos mundo a fora, mas não menos inspirados. Dizia-o também numa demonstração de desprezo pela outra música, a dos sambas e canções, das modinhas, a do "zé-povinho" - uma cusparada de desprezo - e pela gentalha dos violões e cavaquinhos, das gaitas e tamborins, caterva de vagabundos. Ao dizê-lo, estabelecia uma distância, marcava a diferença entre a orquestra de amadores - à qual pertenciam doutor Venceslau Pires da

${ }^{24}$ Ibidem, p. 130.

${ }^{25}$ Ibidem, p. 337. 
Veiga, cirurgião eminente, doutor Pinho Pedreira, juiz da capital, e o milionário e comendador do Papa Adriano Pires - (...) e os vagabundos em serenatas e em desordens, bêbados de má vida. (...) Quando do primeiro casamento da filha (se aquilo se podia chamar de casamento), tivera de suportar a cachaça e a pachouchada daqueles valdevinos, uma canalha, faces de depravação e de deboche: Jenner Augusto, Carlinhos Mascarenhas, Dorival Caymmi. Vez por outra, um homem formado e de família se metia com tal caterva de vagabundos e logo era o pior de todos, como aquele doutor Walter da Silveira cujo rosto nédio dona Rozilda recordava com ódio. Ouvira em Nazareth elogios aos conhecimentos jurídicos do tal Silveira: sumidade nas leis e impoluto. Acreditasse quem quisesse, não ela, dona Rozilda, que o vira a soprar na gaita o passo do siri-boceta, o infame! ${ }^{26}$

Essa extensa citação é importante para demonstrar que, para dona Rozilda, a preferência pelo tipo de música popular indicava automaticamente o caráter da pessoa. Independente de sua posição social, o simples gosto assinalava o nível da pessoa. Até mesmo o advogado supracitado, simplesmente por ter participado da primeira serenata de Vadinho, era também um vadio, como todos os outros da caterva, que apreciavam aquela música. Até o doutor Teodoro, logo que dona Rozilda soube do novo casamento, foi associado a esse tipo de gente simplesmente por tocar um instrumento:

Tão antimusical se fizera, devido a essa corja, que reagira violenta à primeira notícia dos dotes do genro: "sujeito sem compostura, tocador de berimbau". Mais uma vez, certamente, a idiota da filha, sem tino e semvergonha, ia se amarrar a algum malandro para sustentá-lo, carregá-lo às costas, financiando-lhe os víciose as amantes com o suado dinheirinho da Escola ${ }^{27}$.

Somente depois passou a acreditar no caráter de Teodoro, não o vendo mais como um tocador de berimbau, na sua primeira definição, mas sim um músico de nível, com um círculo de relações sociais adequadas. Porque era isso que dona Rozilda sempre quis, frequentar a alta sociedade; o que acreditava ter conseguido quando do segundo casamento da filha.

Alto nível, então, tinham aqueles que gostavam de música erudita. Essa posição reforça a dicotomia popular versus erudito, acrescentando-lhe a distinção social. Dois enganos de dona Rozilda, pois não só a orquestra dos Filhos de Orfeu era

\footnotetext{
${ }^{26}$ Ibidem, p. 351 a 352.

${ }^{27}$ Ibidem, p. 352.
} 
composta por pessoas das mais distintas posições sociais, como também há discordâncias, na obra, quanto a essa música ser realmente erudita:

No seleto mundo da música erudita - e aqui vai o adjetivo pelo que vale, dele discordava dona Gisa como mais adiante se verá -, nesse ambiente impregnado de insignes sentimentos, não tinha vez e lugar desigualdades de dinheiro e origem social, ali se diluíam as diferenças de classe e de fortuna para que se formasse a super-casta dos Filhos de Orfeu, irmãos na arte. $^{28}$

E como anunciado, pouco "mais adiante", se vê um debate na tentativa de classificar a verdadeira música erudita, protagonizado por dona Gisa, amiga de Flor que adotou a Bahia, mas nasceu nos Estados Unidos. Sua opinião leva a discussão sobre música erudita para outro patamar:

Para dona Gisa, música erudita era somente a grande música imortal de Beethoven e Bach, de Brahms e de Chopin, de alguns raros e sublimes compositores: sinfonias e sonatas, músicas para serem ouvidas no silêncio e no recolhimento, para as grandes orquestras, os regentes famosos, os intérpretes de classe internacional. Para apreciadores capazes de ouvir e de entender. Ela vinha dessa música, e no seu purismo sectário, em seu extremo formalismo, classificava tudo o mais de porcaria, "para quem não possui educação musical". (...) Entenda-se, aliás: naquela definição violenta "tudo uma porqueira" - não incluía dona Gisa a música dita popular, expressão do povo, ardente e pura. Ao samba e às modinhas, aos "spirituals", aos cocos e às rumbas, tinha respeito e estima. Não tolerava, isso sim, a fatuidade dessa música sem força e sem caráter, feita em sua opinião, para o mau-gosto da classe média, incapaz de sentir a beleza e se comover com os grandes mestres. ${ }^{29}$

A esses comentários, outro personagem, doutor Ives, responde escandalizado que ela deixou de fora a verdadeira música erudita: as óperas. Dando prosseguimento à polêmica, a longa citação que se segue é apenas uma parte do colóquio em torno do tema:

Doutor Ives abria a boca, num alarme: quanto pernosticismo, gringa metida a sebo! Onde ficavam as óperas - me diga, professora - "Il Rigoletto", "O Barbeiro de Sevilha", "O Palhaço", "O Guarani", do nosso imortal Carlos Gomes - ouça, dona Gisa, nosso, brasileiro, nasceu em Campinas -, a levar o nome da pátria amada aos palcos do estrangeiro por entre aplausos? Onde ficavam essas maravilhas, com suas árias, seus duetos, seus barítonos e seus baixos, suas primas-donas? Se isso não era música erudita, então o que era? Por acaso sambas e rumbas, modinhas e tangos? (...) Ora, siá dona Gisa, se assunte, porque nessa matéria (como de resto em tudo mais) doutor Ives é sumidade. Alteando a voz e o gesto de vitória, ele pergunta: onde ela encontrará algo de mais refinado do que uma boa opereta como "A Viúva

${ }^{28}$ Ibidem, p. 371.

${ }^{29}$ Ibidem, p. 376. 
Alegre", "A Princesa dos Dólares", ou "O Conde de Luxemburgo"? (...) Assente em bases concretas, a cultura musical do clínico resultava do conhecimento vivo - quando estudante, indo ao Rio numa caravana, assistira das torrinhas do Teatro Municipal, com entradas de favor, a algumas óperas montadas e cantadas pela "Grande Companhia Musicale di Napoli". Deslumbrou-se com os espetáculos, com as melodias e as vozes dos barítonos e dos sopranos, dos tenores e dos contraltos. Não os ouvira em discos de vitrola, dona Gisa, e sim de corpo presente, vendo-os no palco a brilhar no esplendor de seu gênio, a Tito Schippa, a Galli Cursi, a Jesus Gaviria, a Bezanzonni, cantando a "Traviata", a "Tosca", "Madame Butterfly", "Il Schiavo" (também do nosso Carlos Gomes, minha cara). Vira depois todos os maravilhosos filmes de cinema - não perdera um só - com as melhores operetas interpretadas por Jan Kepura e Martha Egerth, por Nelson Eddy e Jeanette Mac Donald. Por acaso os vira dona Gisa? Todos, sem perder nenhum $?^{30}$

Dona Norma, outra amiga, fala "que não entendo nada, mas ouço de tudo, porque qualquer coisa me diverte, até sino em toque de finados acho bonito"31. E, então, chega a vez de dona Rozilda, que nada diz, mas tem sua opinião bem definida sobre o assunto:

Para dona Rozilda era uma blasfêmia comparar a música da orquestra de amadores, papa-fina para ouvidos delicados, com essa bombachata de moleques ao violão. Boa pessoa, dona Norma, bem casada, rica, mas seus gostos eram de gentinha... Por outro lado, a professora só por ser americana era metida a catedrática. Pode ser que dona Gisa, lá em seu país, tivesse conhecido coisa melhor, mais erudita, superior aos Filhos de Orfeu. Ela, dona Rozilda, duvidava e desconhecia. A seu ver eles eram o non-plus-ultra até prova em contrário. Uns senhores daqueles, da mais alta distinção... ${ }^{32}$

Como já se notou, a distinção não é feita pela qualidade musical, mas sim pelo preconceito de dona Rozilda pela música de Vadinho. Aquele tipo de música lembrava o antigo genro, seu tipo de vida, todo o desgosto que passou e todas as possibilidades de ascensão social jogadas fora com o primeiro casamento de sua filha. A música de Teodoro representa o ponto máximo de sua ascensão, seu ápice. Fazia agora parte da sociedade da Bahia, o círculo de amizades do doutor o comprovava. E era a música que unia o doutor - e indiretamente dona Rozilda - a essa sociedade.

Dona Rozilda não compreende que a música que ela acredita ser de alto nível, na verdade, é apenas um nível intermediário entre o popular e o erudito, sendo oúltimo

\footnotetext{
${ }^{30}$ Ibidem, p. 376.

${ }^{31}$ Ibidem, p. 377.

${ }^{32}$ Ibidem, p. 377 a 378.
} 
representado na obra por dona Gisa e doutor Ives, apesar de não haver por parte do narrador uma definição final do que realmente seria a música dita erudita. Isso porqueo narrador coloca as diversas opiniões em debate, mas não estabelece qual seria a vencedora na discussão. Assim como também não o faz com relação às escolhas de dona Flor, posto que surge a dúvida: onde Flor fica? A qual mundo definitivamente pertence? Ao de Vadinho ou de Teodoro?

Flor fica nos dois. Quando casada com Vadinho, ia com o marido a festas, adorava as serenatas que ele fazia para pedir perdão por seus erros, escutava sambas no rádio, foi com ele jantar e dançar no Pálace, não esquecendo a passagem de Sílvio Caldas em Salvador, com direito a almoço em sua casa, serenata para ela e espetáculo ao lado de Vadinho.

No entanto, após o casamento com Teodoro, sua vida mudou. Adaptou-se ao novo marido, às suas manias, ao seu sexo, à sua música. Gostava; não entendia muito e até lhe causava sono, mas gostava. Como em outros sentidos, o doutor não a completava. Dona Flor sentia falta de muitas coisas. Isso porque o que se dá na obra é uma questão dialética na qual a tese e a antítese são Vadinho e Teodoro - seus respectivos mundos, suas personalidades e seus tipos de música, e Flor é uma síntese dos dois.

Por isso a necessidade da volta de Vadinho e sua permanência no mundo dos vivos, pois só assim Flor se completa, com seus dois maridos, tão diferentes e tão opostos como as duas donas Flor que existem dentro dela. É o que se vê na explicação de Vadinho quando retorna do mundo dos mortos:

Gosto tanto de ti (...) com amor tamanho que para te ver e te tomar nos braços, rompi o não e outra vez eu sou. Mas não queiras que eu seja ao mesmo tempo Vadinho e Teodoro, pois não posso. Só posso ser Vadinho e só tenho amor para te dar, o resto todo de que necessitas quem te dá é ele; a casa própria, a fidelidade conjugal, o respeito, a ordem, a consideração e a segurança. Quem te dá é ele, pois o seu amor é feito dessas coisas nobres (e cacetes) e delas todas necessitas para ser feliz. Também de meu amor precisas para ser feliz, desse amor de impurezas, errado e torto, devasso e ardente, que te faz sofrer. Amor tão grande que resiste à minha vida desastrada, tão grande que depois de não ser voltei a ser e aqui estou. Mas não para permanecer contigo, ser tua companhia, teu atento esposo, para te guardar constância, para te levar de visita, para o dia certo do cinema e a hora exata de dormir - 
para isso não, meu bem. Isso é com o meu nobre colega de chibiu, e melhor jamais encontrarás. Eu sou o marido da pobre dona Flor, aquele que vai acordar tua ânsia e morder teu desejo, escondidos no fundo de teu ser, de teu recato. Ele é o marido da senhora dona Flor, cuida de tua virtude, de tua honra, de teu respeito humano. Ele é tua face matinal, eu sou tua noite, o amante para o qual não tens nem jeito nem coragem. Somos teus dois maridos, tuas duas faces, teu sim, teu não. Para ser feliz, precisas de nós dois. Quando era eu só, tinhas meu amor e te faltava tudo, como sofrias! Quando foi só ele, tinhas de um tudo, nada te faltava, sofrias ainda mais. Agora, sim, és dona Flor inteira como deves ser. ${ }^{33}$

Esses três pontos apresentados parecem coincidir numa proposta de apresentar a música como um forte elemento formador ou representante de uma identidade, em especial, tratando-se aqui, da identidade regional (baiana). O livro, portanto, é um espaço para a discussão desse assunto. Quem seria mais representativo? Vadinho ou Teodoro? E, por consequência, que música é a mais representativa?

Uma primeira resposta seria Vadinho. Sua vida desregrada, seu jeito de arranjar dinheiro, levar sua vida na malandragem, ser ao mesmo tempo herói e anti-herói seduz o leitor. Ao mesmo tempo, desperta pena quando se observa a luta na qual se encontra em seus momentos de arrependimento diante da chorosa e infeliz esposa. Como escreveu Roberto DaMatta, em um de seus estudos sobre a sociedade brasileira:

No Brasil, como em outras sociedades hierarquizantes, o personagem - de modo inverso - nunca deve ser o homem comum, aquele que na dramatização representa a si mesmo por meio de sua rotina achatada e desinteressante. Ao contrário, (...) o herói deve sempre ser um pouco trágico para ser interessante, com sua vida sendo definida por meio de uma trajetória tortuosa, cheia de peripécias e desmascaramentos. ${ }^{34}$

E, como a leitura da obra demonstra, foi conturbada a passagem de Vadinho, que é realmente um personagem trágico e problemático, pela vida, "cheia de peripécias e desmascaramentos", tanto a primeira, como até mesmo a segunda. $\mathrm{E}$ talvez seja por isso que Teodoro não desperte o interesse da mesma forma que seu

\footnotetext{
${ }^{33}$ Ibidem, p. 520 a 521.

${ }^{34}$ Roberto Da Matta, Carnavais, malandros e heróis - para uma sociologia do dilema brasileiro, 1997b, p. 257.
} 
antecessor. Sua vida é muito regrada, organizada e metódica, de "rotina achatada e desinteressante".

Importa lembrar que Vadinho morre nas primeiras linhas da obra. Seu caráter e personalidade são apresentados ao leitor um pouco pelo narrador, mas muito mais pelos comentários e pensamentos dos personagens. Flor, principalmente, porém também dona Rozilda, dona Gisa, dona Norma, as outras vizinhas, os amigos do falecido, o padre, o banqueiro, e muitos dos outros personagens tecem, a todo momento, pareceres sobre Vadinho, ora qualificando-o como o "porreta"35, ora desclassificando-o como o pior dos maridos, "um demônio do inferno"36, na avaliação de dona Rozilda. Questiona o narrador:

Quem era Vadinho? Qual sua verdadeira fisionomia? Quais suas exatas proporções? Era banhada de sol ou coberta de sombra sua face de homem? Quem era ele, o jogral da elegia, o porreta da frase de Paranaguá Ventura, ou o desprezível malandro, o mordedor incorrigível, o mau marido na voz da vizinhança, das amizades de dona Flor? Quem melhor o conhecera e melhor agora o definia: as piedosas frequentadoras da missa das seis na Igreja de Santa Tereza ou os irrecuperáveis habitués do Tabaris, "a bola girando na roleta, o baralho e os dados, a última parada"?37

Essa pergunta, assim como outras, não será respondida pelo narrador. Como já foi referido quando da discussão sobre o que seria a verdadeira música erudita, o narrador apresenta as opiniões de seus personagens para que o leitor reflita e opte por sua opinião. Não há também resposta pronta sobre Vadinho. Sua vida vai sendo contada, lembrada, comentada, a ponto de o narrador perguntar e colocar a dúvida explicitamente ao leitor:

Herói? Ou será ele o vilão, o bandido responsável pelos sofrimentos da mocinha, no caso dona Flor, esposa dedicada e fiel? Esse já é outro problema, desligado da questão literária a preocupar poetas e prosadores; talvez até mais difícil e grave, e ficará a vosso cargo dar-lhe resposta, se obstinada paciência vos conduzir até o fim destas modestas páginas. ${ }^{38}$

\footnotetext{
${ }^{35}$ Jorge Amado, Op. Cit., 1966, p. 42.

${ }^{36}$ Ibidem, p. 59.

${ }^{37}$ Ibidem, p. 52.

${ }^{38}$ Ibidem, p. 46.
} 
Já o doutor Teodoro, devido a seu caráter ilibado, não sofre censuras, seja do narrador ou dos demais personagens. Nem mesmo dona Flor consegue entender por que não se sente feliz, como nesta passagem em que pensa a respeito de seu segundo marido:

Para que melhor? Quem sou eu para exigir de ti, querido meu, seja o que seja? Que te trouxe eu, que bens coloquei no meu prato da balança conjugal para equilibrar com o teu, tão pleno do dinheiro à romanza no fagote, do saber à fina educação, e essa limpidez, essa decência? Nada te trouxe, nada te acrescentei, e não sou translúcida e perene, não tenho essa tua luz meridiana, sou feita também de sombras, de matéria noturna e transitória. Sou tão pequena para tua altura, Teodoro. ${ }^{39}$

Essa posição dualista entre Vadinho e Teodoro remete a outro trabalho de DaMatta, especificamente sobre o livro Dona Flor e seus dois maridos. Nele, o autor propõe uma visão tríplice, diferente da visão dualista geralmente enfatizada no pensamento brasileiro, isto é:

(...) um conjunto de interpretações "oficiais"do Brasil, todas marcadas pela
fascinação com um dualismo do tipo: exploradores/explorados; Norte/Sul;
litoral/interior; preto/branco; Brasil moderno/Brasil arcaico;
feudalismo/capitalismo; escravos/senhores; Império/República; quando-
na verdade - as vertentes interpretativas mais duradouras do cenário
social brasileiro falavam (e ainda falam) em três elementos, tal qual
aprendemos na escola primária e na "vida". (...) Assim, temos
céu/inferno/purgatório, preto/branco/mulato, preto/branco/índio,
sim/não/mais ou menos, como se, ao lado da visão dualística, uma
perspectiva triangular ou triádica corresse oculta, inconscientemente,
constituindo um discurso dos brasileiros sobre o Brasil que é também
importante. ${ }^{40}$

Dessa forma, ao se questionar sobre quem escolher, pensando em Vadinho e Teodoro, Flor não sabe que decisão tomar e reflete: (...) "Por que cada criatura se divide em duas, por que é necessário sempre se dilacerar entre dois amores, por que o coração contém de uma só vez dois sentimentos, controversos e opostos?"41. Divide-se porque Flor sempre optou por escolher, seja quando escolheu Vadinho contra a vontade de sua mãe, como quando numa metáfora musical escolheu a vida nova com doutor Teodoro:

\footnotetext{
${ }^{39}$ Ibidem, p. 406.

${ }^{40}$ Roberto DaMatta, A Casa e a Rua: espaço, cidadania, mulher e morte no Brasil, 1997a, p. 71.

${ }^{41}$ Jorge Amado, Op. Cit., 1966, p. 493.
} 
Vinha dona Flor de outras músicas, mas não das altas notas clássicas de Bach e de Beethoven, das sinfonias e sonatas, como Dona Gisa na meia luz requintada do alemão. Vinha das melodias populares, das violas seresteiras, dos boêmios cavaquinhos, das gaitas de riso cristalino. Devia agora ajustar-se à orquestra de amadores, à grave melodia dos oboés, dos trompetes, dos violoncelos, aos acordes conspícuos do fagote. Tirar a cabeça daquelas outras músicas a fazê-la desatenta, perdida em obscuros caminhos, no mistério das encruzilhadas. Devia sepultar nos ensaios do fagote, nas escalas da orquestra, as lembranças de melodias mortas, de um tempo extinto, do que foi e já não era. ${ }^{42}$

Porém, quando precisa escolher definitivamente entre Teodoro e o Vadinho que voltou dos mortos, não escolhe. Sobre isso, DaMatta escreveu um posfácio a uma edição do livro intitulado justamente $A$ mulher que escolheu não escolher, no qual analisa sob nova perspectiva essa:

(...) esplêndida heroína de Jorge Amado que, contrariando as regras dos affaires du coeur ocidentais, ultrapassa a trágica obrigação de escolher que liquidou Heloísa, Julieta, Isolda, Ema, Luísa e tantas outras mulheres apaixonadas e alcança uma inadmissível, porque impensável, felicidade com dois maridos! ${ }^{43}$

Surge, não analisando dualisticamente, mas da forma triádica estabelecida por DaMatta, uma outra opção para definir quem é mais representativo: não é Vadinho, nem Teodoro, mas, sim, dona Flor. O que parece ser o mais correto, tendo em vista o final da obra:

Do braço do marido felizardo, sorri mansa dona Flor: ah! essa mania de Vadinho ir pela rua a lhe tocar os peitos e os quadris, esvoaçando em torno dela como se fosse a brisa da manhã. Da manhã lavada de domingo, onde passeia dona Flor, feliz de sua vida, satisfeita de seus dois maridos. ${ }^{44}$

E, por entender aquelas palavras de Vadinho, quando lhe diz que com os dois ela se torna completa, pode dona Flor aceitar sua nova condição de mulher casada com dois maridos, não traindo a nenhum e nem a si mesma.

É nesse triângulo - Flor, Vadinho e Teodoro; casa, rua e outro mundo; certo, errado e situação; marido, mulher e amante - que triunfa sobre as escolhas impostas pelos dualismos rotineiros que vamos encontrar a chave para a compreensão desse romance. ${ }^{45}$

\footnotetext{
${ }^{42}$ Ibidem, p. 384.

${ }^{43}$ Roberto DaMatta, A mulher que escolheu não escolher, 2008, p. 463.

${ }^{44}$ Jorge Amado, Op. Cit., 1966, p. 534.

${ }^{45}$ Roberto DaMatta, Op. Cit., 2008, p. 465.
} 
Acrescente-se a isso a questão musical. Aceitando sua nova condição, Flor não precisa mais enterrar a música de Vadinho. Ela sabe ser uma síntese dos dois maridos, pertencer aos dois mundos, necessitar dos dois caráteres, que são seus também. Flor aprende, enfim, a dançar as duas músicas, a de Vadinho e a de Teodoro.

\section{Referências}

AMADO, Jorge. Dona Flor e seus dois maridos: história moral e de amor. São Paulo: Martins, 1966.

AMADO, Jorge. Dona Flor e seus dois maridos: história moral e de amor. São Paulo: Companhia das Letras, 2008.

DAMATTA, Roberto. A Casa e a Rua: espaço, cidadania, mulher e morte no Brasil. Rio de Janeiro: Rocco, 1997a.

DAMATTA, Roberto. Carnavais, malandros e heróis - para uma sociologia do dilema brasileiro. Rio de Janeiro: Rocco, 1997b.

DAMATTA, Roberto. A mulher que escolheu não escolher. In: AMADO, Jorge. Dona Flor e seus dois maridos: história moral e de amor. São Paulo: Companhia das Letras, 2008.

Fundação Casa de Jorge Amado. Disponível em:

<http://www.jorgeamado.org.br/?page_id=148\&lang=pt\&obra=848\&start=20\#o bra>. Acesso em: 02 set, 2018.

\section{Referência para citação deste artigo} NEDEL, Paulo. A dialética da música em Dona Flor e seus dois maridos. Revista PHILIA | Filosofia, Literatura \& Arte, Porto Alegre, volume 1, número 2, p. 440 - 460, outubro de 2019. 